\title{
The Development of Inquiry Science Worksheet to Facilitate the Process Skills
}

\author{
Margaretha Ordo Servitri ${ }^{1}$, Wulan Trisnawaty ${ }^{2}$ \\ ${ }^{1}$ Study Program of Elementary School Teacher Education, STKIP Bina Insan Mandiri, Surabaya, Indonesia \\ ${ }^{2}$ Study Program of Mathematics Education, STKIP Bina Insan Mandiri, Surabaya, Indonesia
}

\begin{tabular}{|c|c|}
\hline Article Info & ABSTRACT \\
\hline Article history: & \multirow{9}{*}{$\begin{array}{l}\text { This research aimed for developing Inquiry Worksheet to facilitate the } \\
\text { process skill. Inquiry Worksheet gave the opportunity for student to make } \\
\text { good observations in giving hypothesis, designing the experiment, collecting, } \\
\text { analyzing, and inferring the data. To involve the students in Inquiry process } \\
\text { is the important point in Science lessons which can help the students to } \\
\text { develop Science literacy and give the opportunity to drill their Science } \\
\text { process skill. This research used the steps of developing } 4 \mathrm{P} \text { but the fourth } \\
\text { step was not used, this analysis used the descriptive qualitative. Based on the } \\
\text { validation result showed the Lesson Plan (RPP) and Inquiry Worksheet } \\
\text { (LKS) had been developed were in valid category. The implementation of the } \\
\text { good Lesson Plan for Evaluation Results was classically achieved. The } \\
\text { process skill obtained } 100 \text { for the average score. For pretest and posttest, the } \\
\text { students obtained } 82,85 \text { and } 57,14 \text {. Learning using the Inquiry worksheet } \\
\text { showed good responses by the students. The conclusion of this research was } \\
\text { Inquiry Worksheet competent to facilitate the process skills. }\end{array}$} \\
\hline Received Feb 12, 2018 & \\
\hline Revised Apr 21, 2018 & \\
\hline Accepted Jun 10, 2018 & \\
\hline & \\
\hline Keywords: & \\
\hline Developed Worksheet & \\
\hline Inquiry & \\
\hline Process Skills & \\
\hline
\end{tabular}

Copyright $(2018$ Institute of Advanced Engineering and Science. All rights reserved.

\section{Corresponding Author:}

Margaretha Ordo Servitri,

Study Program of Mathematics Education,

STKIP Bina Insan Mandiri,

Jalan Raya Menganti Kramat No. 133, Wiyung, Surabaya, Indonesia.

Email: margarethaordo@stkipbim.ac.id

\section{INTRODUCTION}

Education enormously contributes to progress of a nation. Through education, Indonesia can release from the ignorant, underdeveloped, and developed human resources for gaining the confidence to stand and compete with other nations in the world. Developed education is an education that can develop people's potentials, nurture the will and motivate the generations to explore various potentials, and develop them optimally for whole the development of community [1].

Literally, Science can be referred as knowledge of nature, studying about the events occurs in it. Essentially, Science is considered as product, process, and developed manner [2]. It means, studying Science has scientific process, scientific result (product), and scientific developed manner. The three of them are related to the Science learning process and they should contain all of them.

Inquiry learning is activities which involve all the maximum students' capabilities to find and examine items (objects, human or events) systematically, critically, logically, and analytically to they can formulate their findings confidently. This research develops Inquiry worksheet, it helps the students finding their own concept through the direct experiences and drilling their scientific process skills [3].

Harlen says that quoted by Zeidan \& Jayosi, science process skills are known as procedural skills, experimental and investigating science habits of mind or scientific inquiry abilities [4]. Appropriate selections of science process skills can be taught and studied in the early years of primary school the basic 
skills considered as prerequisite to learning the integrated skills. The young students can be given the opportunity to observe, handle things and explore the environment [4].

Besides teaching science with the orientation of certain intelligences, important in science learning, science process skills are also an indicator of how one can master the science subject. Mastery of science process skills is an important way to gain knowledge quoted by Samsudin et al [5]. Taconis, FergusonHessler \& Broekkamp in Samsudin et al also say that students need to get acquainted and master the science process skills by conducting scientific investigation and their learning quoted by Samsudin et al [5]. However, applications of science process skills as a way to master the sciences are still short from the goal [5]. This situation is caused by the pedagogy of teachers who do not model the processes of scientific exploration and students' thinking skills [5].

According to Rustaman in Anam, forcing cognitive in education system is too abstract (inexplicit), passive and rigid makes learning process unpleasant and burdensome. [6]. All of these have cut the students' characters, they become uncreative, unconfident, depressed and stressed, and dislike studying. School is not only a place for the students to study, yet in their environment too. It is the time to build an understanding to the students that not only in school they obtain their lessons but also in their environment. This Inquiry approach can help the teachers to build the understanding. This approach persuades the students to be independent although they study without teacher's guidance. The $2013^{\text {th }}$ Curriculum (Kurikulum 2013) follows: learning process in the school, classes, and communities; and the background, characteristic, and capability experiences of the students.

The result of the observation of $2013^{\text {th }}$ Curriculum (Kurikulum 2013) showed some of teachers have done practicum using Worksheet (LKS) which has been structured, so the students did as the instructions. Consequently, the process and product skills of students disappeared and underdeveloped [7]. The effects showed when they are in $4^{\text {th }}$ grades on the practice exams, many students failed because of the wrong planning and execution of experiments. In fact, many worksheets were only contained summaries, sample questions, and follow up exercises. So, worksheets was only forced the students on cognitive aspect, while process skill and skill social were less in psychometric aspect [7]. Teachers are expected able to develop the learning instruments to drill students' skills to develop their competencies. Teachers need developing the worksheet and drill the students in their process skills, product, psychometric, and social skills. The author expected one of the appropriate alternative worksheet in accordance expectation is Inquiry worksheet. Inquiry worksheet gives the opportunity for students to make good observations in giving hypothesis, designing the experiment, collecting, analyzing, and inferring the data.

Involving students in Inquiry process is an important point in Science lessons which can help the students to develop Science literacy and provide the opportunity to drill their Science process skills. The research also showed when students were involved in Inquiry process, they improved their comprehend understanding to the science materials.

From the description showed that Inquiry learning process enable for the students to be applied because through the applications of self-discovery, students not only acquire skills that able to be applied in their own life, but also give opportunity to students to understand the depth concepts in Science. Thus, the learning process will be more meaningful.

\section{RESEARCH METHOD}

This research can be classified as development research. In this research, Inquiry worksheet need to be developed, but to use Inquiry worksheet, we need the other teaching instruments, those are lesson plan and assessment. The subjects for this research were worksheets and the learning's instruments developed by the researchers and students of SD Kristen Anak Panah grade 4. There were 20 students. According to Thiagarajan, there are 4 steps for the process of development learning's instruments [8]. In this research, the researcher was only examined the development instruments up to the third steps since it limited to a school as a place to researched, that is SD Kristen Anak Panah. In this study, the experimental unit was subjected to treatment with two measurements. The first measurement $\left(\mathrm{O}_{1}\right)$ was performed pretest before treatment given, the second measurement $\left(\mathrm{O}_{2}\right)$ was done posttest after treatment given. We just examined one group without any comparison group [9].

\section{RESULTS AND ANALYSIS}

The teaching instruments which have been developed for this research is Inquiry Science Worksheet (LKS) to facility the process skills of students in grade 4. The teaching instruments which have been developed were Lesson Plan (RPP), Worksheet (LKS), Evaluation Result and Process skills. The instruments which was developed the author have been reviewed and validated by an expert in physics. The validation 
aimed to review the development quality of teaching instruments. The aspects were the instructions, eligibility of contents, process skills, procedure, and questions. According to the validator record, the result of evaluation of validation of Inquiry Worksheet indicated to have good criteria with a little revision then applied in learning process and observation by 2 observers.

The data result by 2 observers of worksheet showed the average assessment of Inquiry Worksheet of both observers / assessor were 3,89 which meant developed Inquiry Worksheet was quite good and able to use with 99,35 reliability score. Based on the validator record, the result of the assessment on the validation of Lesson Plan (RPP) was stated to have good criteria with little revision. The implementation of teaching instruments applied at SD Kristen Anak Panah. The participants were 20 of class 4 Advance students. The researcher acted as a teacher for three meetings.

Analyzing of descriptive research result was commonly in the form of description of the average score and percentages. The following will be described the results of research and analysis of $2^{\text {nd }}$ test data. The Lesson Plan (RPP) is learning activities schedule as a teacher's guidance in doing the teaching procedure in the class; it contained the identities, core competence, basic competence, achievement's indicators, learning objectives, learning materials, time, teaching methods, teaching procedures, assessment, teaching resources. The result of observation on the management of learning in the second trials is. The result showed that the implementation of the learning has been done well. The observers were Science teachers of SD Kristen Anak Panah.

The observation result showed that Inquiry Worksheet of Motion and Force have been done well. Observations have been done by a Science teacher of SD Kristen Anak Panah. All of the data found showed if teaching process using Inquiry Worksheet have reliability over 75\%. It means that this instrument was reliable. Cognitive test used to find students' evaluation result which was counted using mastery of learning objective. The learning objective indicated mastery when the proportion of students' correct answer (p) $\geq$ 0,75 . Likewise, individual and classical indicated mastery if $\geq 85 \%$ of students have been master their learning. The process test was used to find students' evaluation result which was counted using mastery of learning objective. Based on the sensitivity of items, each items indicated sensitive to find the effects of learning because there were no negative items sensitivity. It meant at the beginning of learning, most students did not understand the scientific work process correctly, but after learning using Inquiry Worksheet of Motion and Force, students could answer the problems correctly. The responses of students were 20 students who have joined Teaching and Learning Activities (KBM). Based on the percentage of average of students' opinion known $100,00 \%$ of students have interest in activity's components, $90,74 \%$ of students assumed 'new' for the components, $90,74 \%$ of students assumed the components was easy to do, $100,00 \%$ of students assumed the test was easy to do, $88,89 \%$ assumed 'new' with the problem's model. The students also assumed newly in model of process test and assumed ordinary in cognitive test.

To know what developed Inquiry Worksheet (LKS) have good quality, and then internal validation did. Internal validation towards Inquiry Worksheet (LKS) was done before the worksheet was used while the data taken. The validation was taken by 1 validator. There was some information about the worksheet that was the unclear pictures. According to the validator record, the result of the research towards the validation of Inquiry Worksheet showed the good criteria with little revision.

Beside internal validation, external validation also needed used to the other teachers who taught the same subject. External validation towards Inquiry Worksheet was done while Teaching and Learning Activities progresses, 2 teachers of SD Kristen Anak Panah as validators. The average of Inquiry worksheet assessment of both validator was 3,89. It meant Inquiry worksheet was good and able to use. It is because developed Inquiry worksheet purposed in worksheet criteria which was developed by the previous researcher. He stated if the new developed worksheet must provide the good worksheet compiling requirement. There were some criteria the author should understand in compiling and development the worksheet; those were didactic, language, and technics [10].

Those were the author should be attention for the didactic requirement: purposed in the process to find the concepts so the worksheet is function as 'direction' for students who wanted to know; without differentiate so that the good worksheet can be used well for any students for slow response, ordinary response or fast response.

The language rubric the author used to be the assessment were the language usage, the grammar, simplicity and clarity of the words used, it meant the words used could be understand by the students. Therefore, there were things the author should notice when composing and making sentences for worksheet, those were: using the appropriately language to the students' level; using simplicity and clarity of the words; having a set of lesson according to the students' ability, for example if there is any complicated concept, it can be solved to the simple ones; using shortly and simply sentences; having the appropriate goal learning and taking it as a innovation's sources; having an identity to make administration easier, such as class, 
subject, topic, date, etc. to the technical requirements followed in developing the worksheet include writing (letters), picture, and appearance.

From the criteria followed, the author added and subtracted its criteria which adapted to 2013 curriculum and the characters of Inquiry worksheet themselves. The result of the study that had been done by the researcher in fully terms was the material referred to the 2013 curriculum, the pressure of the process to discover concepts and activities were related to the students' real life, having appropriate goal learning, giving material points and the details, using simply, clear, and understandable sentences, having a set of lesson according to the student's ability, having instructions for the students about the topic discussed, general guideline (procedure of activity). Furthermore, having identities is a must, this can encourage students to learn or work scientifically, developing their capabilities to solve the problems, and also make a conclusion. The other requirements were form of writing, picture, and bibliography.

Discussion about the use of Inquiry worksheet in learning certainly begins with the process skills. The process skills enable students to achieve optimal learning. In training the process skills, the students learn by doing [11]. The discovery of old science will be dropped when the new ones are found because all the concepts basically found through inquiry scientific are still open to be questioned, argued, and fixed. Therefore, the process skills can be instilled through inquiry. The students are equipped with skills to ask, think critically, and seek the possibilities answers to a problem, and be creative [11]. The inquiry worksheet research was used to facilitate the process skills were observed from the level of implementation of each lesson plan which had been obtained in the result of the lesson plan 01 showed score 3,5, it was described good result. The implementation of learning is categorized well if it provides predetermined criteria. This is achieved because inquiry worksheet is a learning that requires the teachers to develop their learning strategies by taking students' responses as well as encouraging them to analyze, interpreting and finding the information [12]. So it can be indicated that this learning perfectly suitable with the function of developed inquiry worksheet.

The development of inquiry worksheet also can be seen from the implementation of worksheet which get score 3 significantly good, it means students can do better, and have discussion with the members of the group by following predetermined scientific procedure. From all aspects in scientific inquiry worksheet showed an increase in scores, it meant inquiry worksheet helped the students to maximize work and practice the scientific work, moreover the average score of process skills was 100 . Beside the students' responses result was positive and interested in learning by process skills, caused the students more deeply to study the materials, and easily to understand and embed in their mind. Some factors lead students' process skills completed and based on the research that had been done showing all the process skill of items' test was sensitive. According to the statement explained that motivating learning can make the students mastery and achieved well in their learning [13].

The development of inquiry worksheet that related to the learning's results obtained 0,96 with High Gain score, moreover the students' response was positive, they interested in learning process, therefore the students more deeply to study the materials, and easily to understand and embed in their mind. Some factors lead students' process skills completed. According to the statement explained that motivating learning can make the students mastery and achieved well in their learning [13]. Based on the research that had been done showing all the process skill of items' test was sensitive. The sensitive questions mean those questions can provide the information if the assessment results are from the process of learning which is oriented in learning process. According to Martaida, learning process skills were better than conventional learning [14]. The development of inquiry worksheet reviewed from the students' responses to the learning showed that the students enjoyed in learning materials using inquiry worksheet, because of the inquiry setting circumstances that accordingly the students and experimental activities was not a new for them.

Students who enjoyed in learning materials with inquiry worksheet successfully ease the students understanding the materials, where most students acknowledged that solving the problem was easy although it was difficult in following the experimental activities. By continuously drilling and helping from the teachers who taught with fun so, the difficulties can be solved. From the questionnaire obtained that scientific work drilling was a new for students but it was easy to follow by students with average percentage $90.74 \%$ of the students can follow the materials easily. The level of clarity materials in the scientific drilling of students indicated easy that is about $100.00 \%$ of students stated coherent. This is strongly supported by the level of students' pleasure on teaching and learning activities using inquiry worksheet. The level of clarity was also supported by a clear explanation as well as an active guiding teacher so that the student could students easily accepted. Based on the positive response of students, a positive response was needed to build students' motivation. Motivation was an internal process (inside the person itself) that would activate, guide and maintain a behavior within a certain time [15-16]. Motivation is one of the factors influencing students' evaluation result, so higher motivation can achieve mastery of indicators. As a result of the research, it was determined that the scientific process skills education increased the students' achievements and scientific 
creativities, however, no meaningful progress was made on their attitudes towards science when compared to the teacher-centered method [17]. The development of inquiry worksheet in learning can also be noticed from students' evaluation result which shows the response of doing cognitive test is easy, although 100\% students tell doing process test is a new for them. Evaluation results showed successful, because most students enjoyed in learning and teacher's explanations could be clearly accepted during the lesson. The results of the test process also showed good, the process test initially considered quite new by the students, but with the seriousness of teacher in guiding students, so that they enjoyed in doing inquiry worksheet, so it helped the students to achieve high scores.

\section{CONCLUSION}

In the analysis data results and discussion of the research result about developing the students' inquiry activities sheets to facilitate the process skills can be concluded that quality of developed inquiry worksheet was in good categorized. The implementation of the developed Lesson Plan was good. Learning using inquiry worksheet obtained Medium Gain score (0.96). The students' process skills during learning activities occurred using inquiry worksheet was $\geq 85 \%$ which classically completed by the students. The response of students towards the learning was also good with $100 \%$ of students enjoyed following the teaching and learning activities. Based on the results of this study, the researcher suggests the study follows necessarily in development similar inquiry worksheet in other subject. Learning with inquiry worksheet is one of the learning that able to drill the process skill to the students. For expecting the skills, hard drilling is needed to build the abilities and independence of students in learning..

\section{ACKNOWLEDGEMENTS}

The authors thank to the Ministry of Research, Technology and Higher Education of the Republic of Indonesia, due to the funding of PDP 2017 for this work.

\section{REFERENCES}

[1] R. Umami, Marungkil, Pasaribu and A. Rede, "Application of Inquiry Methods to Improve Science Learning Outcomes Students of Class IV SD Inpres Bajawali District, Lariang District, North Mamuju Regency," Tadulako Online Creative Journal, vol. 3, no. 2, pp. 157-166, 2014.

[2] S. Sulistiyorini. "Elementary School Science Learning and Its Application in KTSP", pp. 9, 2007.

[3] B. K. Putri \& A. Widiyatmoko. "Development of Integrated Science Worksheets Based on Blood Theme Inquiry in Tengaran Middle School 2”, Indonesian Science Education journal, vol. 2, no. 2, pp.103, 2013.

[4] A. H. Zeidan and M. R. Jayosi., "Science Process Skills and Attitudes toward Science among Palestinian Secondary School Students", World Journal of Education, vol. 5, no. 1, 2015.

[5] M. A. Samsudin, N. H. Haniza, C. A. Talib, H. M. M. Ibrahim., "The Relationship between Multiple Intelligences with Preferred Science Teaching and Science Process Skills", Journal of Education and Learning, vol. 9, no. 1, pp. 53-59, 2015

[6] R. S. Anam. "Effectiveness and Effect of Inquiry Learning Models on Natural Science Learning in Elementary Schools. Mimbar Primary School”, vol. 2, no. 1, pp 80-89, 2015.

[7] Depdiknas (Ministry of National Education in Bahasa), "Guidelines for Preparation of Worksheets and High School Learning Scenarios", Jakarta: Directorate General of Primary and Secondary Education. Directorate of General Secondary Education, 2004.

[8] S. Thiagarajan and M. Semmel, Instructional Development for Trainning Teacher of Exceptiona Children Bloomington: Central for Innovation on Teaching the Handicapped, 1974.

[9] B.W. Tuckman, "Conducting Edicational Research", 2 $2^{\text {nd }}$ Edition, New York: Harcourt Brace Javanovich, 1978.

[10] H. Darmojo and J. R. E Kaligis, Science Education 2. Jakarta: Depdikbud, 1993.

[11] Suprihartiningrum, "Learning strategies", Jakarta: Ar-Ruzz Media, 1993.

[12] Suyono, "Learning and Learning: Basic Theories and Concepts", Bandung: Rosdakarya, 2011.

[13] Dimyati dan Mudjiono," Teaching and Learning", Jakarta: Rineka Cipta dan Depdikbud, 2002.

[14] T. Martaida, N. Bukit, E. M. Ginting, "The Effect of Discovery Learning Model on Student's Critical Thinking and Cognitive Ability in Junior High School”, IOSR Journal of Research \& Method in Education (IOSR-JRME) vol 7 Issue 6 Ver. 1. Nov-Dec, 2017, pp 01-08, DOI: 10.9790/7388-0706010108.

[15] Nur, M dan P. R. Wikandari, "Student-Centered Learning and Constructivist Approaches in Teaching ", Surabaya: PSMS Unesa, 2008.

[16] Nur, M, “Cognitive Development Theories" 3rd mold, Surabaya: PSMS Surabaya State University, 2008.

[17] H, Aktamis \& O. Ergin, "The effect of scientific process skills education on students' scientific creativity, science attitudes and academic achievements”, Asia- Pacific Forum on Science Learning \& Teaching, vol. 9, no. 1, article 4, pp 21, 2008. 


\section{BIOGRAPHIES OF AUTHORS}

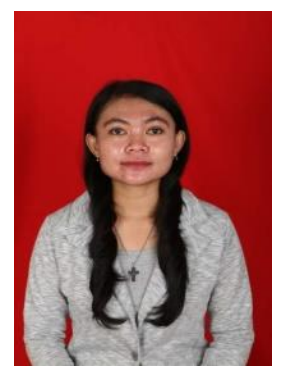

Margaretha Ordo Servitri was born at Lamongan. She graduates her bachelor at State University of Surabaya in PGSD in 2012. She takes her master at Pendidikan Dasar at State University of Surabaya and finished it in 2014. Now, she is a lecturer at STKIP Bina Insan Mandiri on Study Program of Elementary School Teacher Education. She has been actively researching and publishing her research since 2015. She has received three researchers that funding by Ministry of Research, Technologi, and Higher Education of The Republic of Indonesia. This woman has been published her research in various international conferences. She also has copyright of intellectual property in the form of "Inquiry Science Worksheet to Facilitate the Process Skills' instrument.

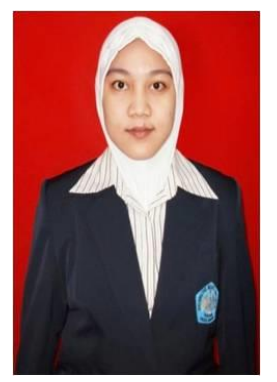

Wulan Trisnawaty was born at Surabaya. She graduates her bachelor at State University of Surabaya in Physics Education in 2009. She takes her master at Science Education at State University of Surabaya and finished it in 2011. Now, she is a lecturer at STKIP Bina Insan Mandiri on Study Program of Mathematics Education. She has been actively researching and publishing her research since 2011. She has received three researchers that funding by Ministry of Research, Technologi, and Higher Education of The Republic of Indonesia. This woman has been published her research in various international conferences. Her research "Self Assesment for Students Performance based on Higher Order Thinking Skills" as been published in the accredited national journal EduLearn that published by Ahmad Dahlan University. She also has copyright of intellectual property in the form of "Self Assessment based on Higher Order Thinking Skills' instrument. 